\title{
Predictors of cardiac arrhythmic events in non coronary artery disease patients
}

\author{
C. Balla ${ }^{1 *}\left(\mathbb{D}\right.$, F. Vitali ${ }^{1}$, A. Brieda ${ }^{1}$, F. Gualandi ${ }^{3}$, A. Ferlini ${ }^{3}$, M. Bertini ${ }^{1}$ and R. Ferrari ${ }^{1,2}$
}

\begin{abstract}
Arrhythmic sudden cardiac death (SCD) represents a major worldwide public health problem accounting for $15-20 \%$ of deaths. Risk stratification to identify patients at risk of SCD is crucial in order to implement preventive measures in the general population. Several biomarkers have been tested exploring different pathophysiological mechanisms of cardiac conditions. Conflicting results have been described limiting so far their use in clinical practice. The use of new biomarkers such as microRNAs and sex hormones and the emerging role of genetic on risk prediction of SCD is a current research topic showing promising results.

This review outlines the role of plasma biomarkers to predict ventricular arrhythmias and SCD in non coronary artery disease with a special focus on their relationship with the genetic biomarkers.
\end{abstract}

Keywords: Sudden cardiac death, Prevention, Biomarkers, Genetic testing

\section{Background}

Sudden cardiac death (SCD), defined as an unexpected fatal event occurring within $1 \mathrm{~h}$ from the onset of symptoms in an apparently healthy subject, remains one of the most challenging tasks in Cardiology [1]. SCDs have mostly arrhythmic origin linked to structural disease (ischemic disease, myocarditis, commotio cordis), cardiomyopathy (hypertrophic cardiomyopathy - HCM, dilatative cardiomyopathy - DCM, restrictive/infiltrative cardiomyopathy - RCM, arrhythmogenic cardiomyopathy - AC) or cardiac channelopathies (Brugada syndrome - BrS, long QT syndrome - LQT, short QT syndrome - SQT, catecholaminergic polymorphic ventricular tachycardia - CPVT). The first cause of SCDs, despite progresses in percutaneous revascularization, remains myocardial ischemia. $\beta$-blocker therapy and implantable cardioverter defibrillators (ICD) are effective in reducing SCD, particularly in patients with severe left ventricular dysfunction [2]. Severe left ventricular systolic dysfunction (left ventricular ejection fraction LVEF $<35 \%$ ) and reduced functional capacity (NYHA class III-IV) are the principal discriminators to stratify the risk of SCD, independently from the etiology of the myocardial disease [2]. However, LVEF is not an

\footnotetext{
* Correspondence: bllcst@unife.it

${ }^{1}$ Cardiology Unit, Azienda Ospedaliero-Universitaria S. Anna di Ferrara, via A. Moro 8, Ferrara-Cona, FE, Italy

Full list of author information is available at the end of the article
}

accurate marker with modest specificity to predict arrhythmic events: only $20 \%$ of patients implanted with an ICD in primary prevention based on low LVEF received an appropriate ICD therapy for ventricular arrhythmia [2] . For cardiac channelopathies or cardiomyopathies with preserved left ventricular function, LVEF and NYHA class are useless for SCD risk stratification.

One half of SCDs occur in patients without any known cardiac disease, and even when a cardiac disorder has been diagnosed before the SCD, more than one third of patients had preserved or mild reduced left ventricular ejection fraction (LVEF) [3]. Therefore, in the large majority of SCDs, our capability to predict the risk is limited [3].

Biomarkers are measurable parameters that serve for several aims in diagnosing, monitoring and therapy addressing diseases. The most widely explored biomarker types are blood biomarkers (plasma, serum, cells) that can be identified in patients with a reasonable cost and minimum invasiveness [4].

They can serve as early diagnosis of sub-clinical disease (surrogate biomarkers). Several blood biomarkers have been evaluated as potential predictors of SCD with conflicting results, probably due to the variety of myocardial disease involved in SCD and the small sample size of the studies [5-10].

We performed a review on the current knowledge of blood biomarkers as predictors of cardiac arrhythmic 
events in non coronary artery disease patients highlighting future perspectives and the impact of genetic diagnosis in the prevention of SCD.

\section{Natiuretic peptides}

Natriuretic peptides are peptide hormones released by the atria and the ventricles in hemodynamic stressful conditions [11]. The main one is the brain natriuretic peptide (BNP), released as prohormone (pre-BNP) and enzymatically divided in two parts: the active peptide BNP and the amino-terminal fragment (NT-pro BNP). Its main actions are improving diuresis and natriuresis and arterial vasodilatation, counteracting renin-angiotensin-aldosterone system and activating the sympathetic nervous system [11]. The role of BNP to predict SCD in HF patients with impaired LVEF or in patients with ischemic disease is well recognized due to its direct link with progressive worsening of HF [12]. Indeed, an association between BNP levels and appropriate ICD shocks or anti-tachycardia pacing (ATP) therapy was shown in a cohort of 345 consecutive ICD patients (mixed ischemic and non ischemic etiology) with a direct link between pre-implantation BNP levels and ICD therapy during time [13] (Table 1). Moreover, Simon et al. showed how elevated NT proBNP serum levels are predictors of major ventricular arrhythmias in patients with non-ischemic cardiomyopathy and mildly impaired left ventricular EF [14] (Table 1).

A meta-analysis to define predictors of SCD and ventricular arrhythmias in ICD patients found that high baseline BNP or NT-proBNP levels were independently linked to ventricular tachyarrhythmia [5].

One of the most accepted theories to explain the relationship between arrhythmic SCD and elevated levels of BNP and NT-proBNP is the so-called mechanoelectric feedback phenomenon [15]. Acute and chronic mechanical stretches of ventricular myocardium lead to an increased production of natriuretic peptides and an activation of mechanosensitive ion channels that cause a conduction delay of the action potential. Prior studies have demonstrated increased ventricular ectopic beats with diastolic stretch in animal models $[16,17]$. These ectopies may result in sustained ventricular arrhythmias in patients with cardiac fibrosis and scarring $[15,17]$.

However, the role of natriuretic peptides in patients without impairment in LVEF is not well defined and its role in cardiac channelopathies is unknown.

\section{Markers of inflammation}

The inflammation cascade was deeply investigated in the past few decades in the pathogenesis of atherothrombosis process and cardiovascular disease. Therefore, research has been focused on possible biomarkers of inflammation that could be linked to coronary artery disease (CAD) and SCD.

C-reactive protein (CRP) is an acute phase reactant protein that rises in response to inflammation. Data from the Physician Health Study showed that high basal levels of CRP were linked with an increased risk of SCD in healthy male physicians in a follow up period of 17 years with an almost 3 fold increased risk for the men at the highest quartile compare to men at the lowest [18]. The mean time from CRP measurement to SCD was 9.2 years. In contrast, a subsequent study in a large cohort of women didn't show a significant correlation between CRP and SCD [6] (Table 1). The long time from CRP measure to SCD event limited the study of a potential association between CRP and SCD.

\section{Free fatty acids}

Dietary fatty acids have been deeply investigated in cardiovascular disease [19].

Non-esterified free fatty acids (NEFAs) are considered pro-arrhythmic on the basis of their properties to modulate potassium and calcium channels and to alter cardiac membrane homeostasis [19]. The Paris Prospective Study I described NEFA as an independent risk factor for SCD in a population of middle-age men [20] (Table 1).

In contrast, long chain $n-3$ polyunsaturated fatty acids (eicosapentaenoic acid and docosahexaenoic acid) are well known anti-inflammatory molecules and their serum levels were linked with a lower risk for SCD [7].. In the Physician' Health Study, blood levels of long chain $\mathrm{n}-3$ fatty acids were inversely related to the risk of SCD in men without known cardiovascular disease [18]. The Cardiovascular Health Study found that higher plasma levels of trans-isomers of oleic acid or trans-18:1 were associated with lower risk of SCD whereas high levels of trans-isomers of linoleic acid or trans-18:2 were associated with higher risk [8] (Table 1). The possible mechanism explaining the antiarrhythmic properties of long chain n-3 fatty acids is not completely understood although in vitro studies suggest an effect on action potential and on sodium and calcium ion channel function [21]. Despite the potential interest of a possible dietary intervention for prevention of SCD [22], a study designed to evaluate the effect of omega- 3 fatty acids on the prevention of ventricular arrhythmias in patients with ICDs found no protective effect from fish oil intake on appropriate ICD shocks [9].

\section{Markers of extracellular matrix remodeling}

Extracellular matrix is involved in ventricular remodeling after acute coronary syndromes or in non-ischemic cardiomyopathies. Imbalance between matrix metalloproteinase (MMPs), and tissue inhibitor of matrix metalloproteinase (TIMPs) leads to ventricular dilatation as a 


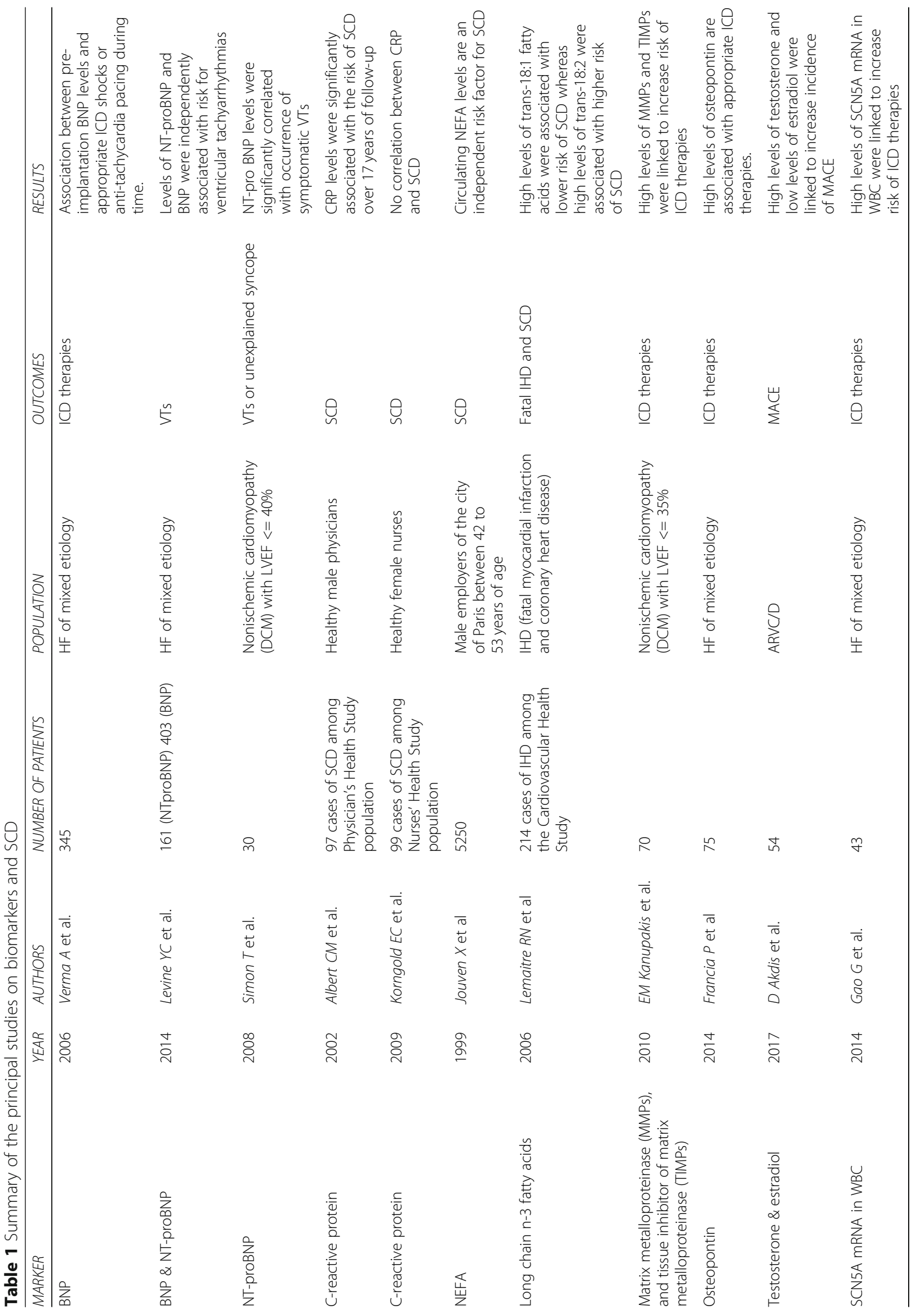


result of degradation of the myocardial fibrillar collagen network which in turn results in myocardial fibrosis [23, 24]. High grade of myocardial fibrosis could be the arrhythmogenic substrate for development of ventricular arrhythmias leading to SCD. Serum C-terminal pro-peptide of collagen type-I, (C-terminal telo-peptide of collagen type-I: CITP), MMPs, and TIMPs are linked with poor prognosis in idiopathic or ischemic dilated cardiomyopathies [25]. Kanoupakis et al. showed that higher levels of CITP, TIMP and MMP-1 were predictors of malignant arrhythmias in patients with non-ischemic dilated cardiomyopathy, reduced LVEF who had received an ICD for primary prevention [23] (Table 1).

Osteopontin (OPN) is an extracellular matrix glycoprotein secreted by macrophages and fibroblasts that plays a determinant role for ECM turnover and fibroblasts' differentiation. Because of his critical role in myocardial profibrotic remodeling, OPN correlates with poor outcomes in patients with acute and chronic HF and predict ventricular arrhythmia occurrence in HF patients with an ICD [26, 27] (Table 1).

Despite this possible pathophysiological mechanism that link extracellular matrix and SCD, collagen turnover markers are not myocardial specific. In addition, most of the trials on this issue are dated and with few patients enrolled.

\section{Emerging blood biomarkers \\ Sex hormones}

In several cardiac conditions, there is a gender difference in terms of phenotype expression of the disease, symptoms and arrhythmic events.

Risk of SCD is higher for females in LQT-2 syndrome and for males in LQT-3 syndrome, whilst no substantial gender difference for SCD is known for LQT-1 [28]. Males with BrS have higher prevalence of type one pattern, symptoms and arrhythmia events compared to females [29, 30]. In ARVD patients, male gender shows an higher risk of ventricular arrhythmias and SCD compared to females [31].

It is conceivable that this gender difference in phenotype expression could be related to specific sex hormone's effect on ion channels function that may be altered in presence of a mutated protein. No clear data are currently available on how sex hormones may act on ion channels although this is an evolving topic.

Recently, high serum levels of testosterone and low levels of estradiol has been linked to major arrhythmic cardiovascular events (MACE) in patients with ARVC/ D. D. Adkis et al. showed that total and free serum testosterone levels are significantly increased in ARVD male patients with MACE compared to those without cardiac events. In the same study lower levels of estradiol were present in females with MACE compared to those without events. In this study, despite the small number of patients enrolled (54 patients), testosterone levels remained independently associated with MACE in males even after adjusting for confounding factors. (Table 1) The same authors showed how in a stem cell-derived ARVC/D cardiomyocyte model, testosterone worsened and estradiol improved cardiomyocyte apoptosis and lipogenesis [32]. This finding is probably due to the testosterone capacity to increase apoptosis ratio and lipid accumulation in cardiomyocytes leading to a more favorable arrhythmic substrate. Estradiol has opposite action on apoptosis and lipid accumulation of cardiomyocytes.

\section{SCN5A mRNA}

Splicing is a co-transcriptional mechanism leading to the mature RNA where introns are removed in order to get the messenger RNA (mRNA) able to be exported in the cytoplasm. By alternative splicing a large mRNA population is generated, including several isoforms, which contribute to the huge protein diversity and expression specificity of human genes. In HF patients, chronic activation of neuroendocrine system, tissue hypoxia and LV dysfunction increase the alternative splicing of the sodium voltage-gated channel $\alpha$ subunit type V (SCN5A) generating truncated variants that result in nonfunctional channels [33].. During HF, $>50 \%$ of SCN5A gene transcripts are prematurely truncated and non functional with an $80 \%$ reduction of the cardiac $\mathrm{Na}+$ current [34]. Levels of SCN5A mRNA variants in circulating white blood cells (WBCs) were strongly linked to myocardial tissue levels. Moreover, in an HF population of mixed etiology with an ICD, there is a correlation between circulating SCN5A variant levels and an ICD intervention. Patients who had received an appropriate ICD therapy showed higher levels of SCN5A variants compared to controls and to patients without an ICD event [35]. More research is necessary to indicate SCN5A mRNA as a predictor for SCD in clinical practice (Table 1).

\section{The role of genetic diagnosis}

Genetic diagnosis is now considered compulsory in all Mendelian diseases. The identification of the genetic bases of SCD is relevant for both acquired diseases and inherited arrhythmia syndromes, but the benefit of this information to reduce the burden of SCD varies between these two groups.

Population studies have demonstrated an higher risk of SCD in families with a previous history of SCD in a first-degree relatives [36-38].

These findings from familial studies have driven the search for common genetic variants able to identify individuals at risk of SCD in acquired conditions, such as coronary artery disease. As a consequence, genetic 
susceptibility to SCD has been shown to be largely determined by common genetic variants (single nucleotide polymorphism (SNPs) (e.g polymorphisms in the KCNQ1 and SCN5A genes), usually located on genes modulating electrophysiological parameters [39-41]. Genome Wide Association Studies (GWAS) are another approach that allows to evaluate all common genetic variants in the genome in normal individuals and in patients with specific diseases, leading to the identification of novel genetic findings contributing to SCD risk [42, 43].

The evidence of a low statistical power in individual SNPs associated with SCD determined the creation of genetic risk scores based on the combination of genomewide significant variants. This approach currently represents the best option to predict risk of SCD in acquired conditions such as coronary artery disease [44].

A significant part of SCD cases occurring in young individuals are related to inherited arrhythmia syndromes. Cardiac channelopathies are caused by mutations in genes that regulate the expression of cardiac ion channels, responsible for the normal propagation of the excitatory stimuli in the heart [45]. Together with diagnosis, confirmation and therapeutic strategy definition, one of the goals of genetic testing in these arrhythmic syndromes is to improve the prediction of risk of adverse events in every single patient, based on its own genotype.

To date, the prognostic value of genetic testing is highest for LQTS, where a gene-specific profile for the risk of SCD is well established [28, 46].. A risk stratification scheme has been proposed for LQTS patients, integrating clinical parameters such as gender and QT interval duration as well as genetic information from the gene in which the causative mutation has been discovered; this approach led to the identification of some highly malignant LQTS variants [47]. In patients with dilated cardiomyopathy lamin $\mathrm{A} / \mathrm{C}$ gene mutations have been associated with high risk of SCD, potentially identifying patients where a more aggressive electrophysiological follow up might be necessary.

Unfortunately, genetic information contributes less to risk stratification in other channelopathies or cardiomyopathies, in which the yield of DNA screening is low and the genotype/phenotype correlations are less defined.

The large amount of genetic data may evolve into a promising approach to quantify the risk of SCD, particularly early on in life. Nevertheless, the important potential use of genetic-based risk stratification is counterbalanced by the complexity to interpret the susceptibility of different genotypes, also considering that DNA variants might be influenced by a mutual interaction and also cooperate with the environment.

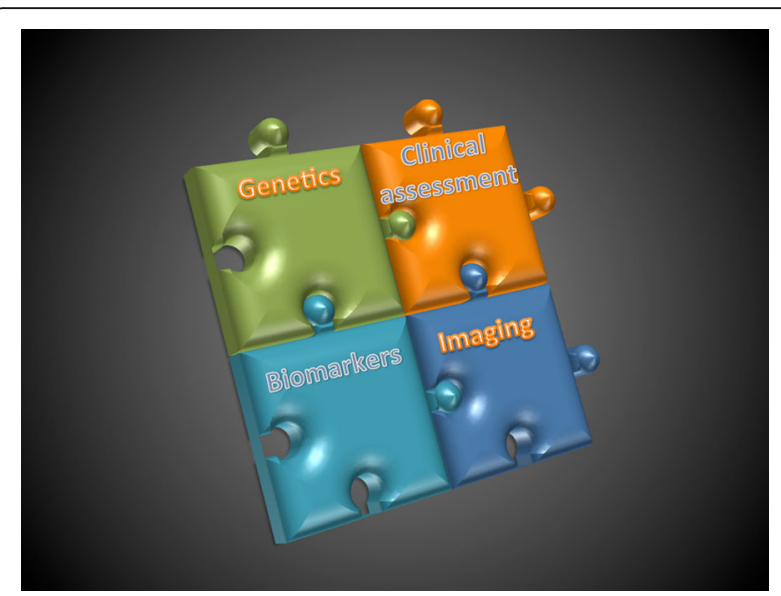

Fig. 1 A multimarker strategy that combine biomarkers, genetic, clinical assessment and imagine may optimize SCD risk prediction in clinical practice

Psychosocial impact of a positive genetic result should also be taken into account.

\section{Conclusions}

Despite significant progress in the development of invasive and non-invasive techniques to identify subjects at risk for SCD, the goal is not fulfilled. Several biomarkers are currently used or have shown potential application in diagnostics, prognosis and treatment response in cardiac conditions. Classical candidate biomarkers of SCD failed to show solid and convincing results, probably due to the small sample size of the studies and the long time from the measure to the event. Integration of single biomarkers into a multimarker approach is promising and potentially useful for SCD risk prediction (Fig. 1). Blood biomarkers monitoring different pathophysiological mechanisms combined with each other or complemented by imaging techniques and the emerging role of genetic may provide important information on disease progress and risk of adverse outcomes.

\section{Authors' contributions}

All authors read and approved the final manuscript.

\section{Competing interests}

The authors declare that they have no competing interests.

\section{Publisher's Note}

Springer Nature remains neutral with regard to jurisdictional claims in published maps and institutional affiliations.

\section{Author details}

${ }^{1}$ Cardiology Unit, Azienda Ospedaliero-Universitaria S. Anna di Ferrara, via A. Moro 8, Ferrara-Cona, FE, Italy. ${ }^{2}$ Maria Cecilia Hospital, GVM Care \& Research, Cotignola, Italy. ${ }^{3}$ Department of Medical Sciences, Unit of Medical Genetics, University of Ferrara, Ferrara, Italy. 


\section{Received: 13 November 2018 Accepted: 16 April 2019 Published online: 02 May 2019}

\section{References}

1. Straus SM, Bleumink GS, Dieleman JP, van der Lei J, Stricker BH, Sturkenboom MC. The incidence of sudden cardiac death in the general population. J Clin Epidemiol. 2004;57(1):98-102.

2. European Heart Rhythm A, Heart Rhythm S, Zipes DP, Camm AJ, Borggrefe M, Buxton AE, Chaitman B, Fromer M, Gregoratos G, Klein G, Moss AJ, Myerburg RJ, Priori SG, Quinones MA, Roden DM, Silka MJ, Tracy C, Smith SC Jr, Jacobs AK, Adams CD, Antman EM, Anderson JL, Hunt SA, Halperin JL, Nishimura R, Ornato JP, Page RL, Riegel B, Priori SG, Blanc JJ, Budaj A, Camm AJ, Dean V, Deckers JW, Despres C, Dickstein K, Lekakis J, McGregor K, Metra M, Morais J, Osterspey A, Tamargo JL, Zamorano JL, American College of C, American Heart Association Task F, European Society of Cardiology Committee for Practice G. ACC/AHAVESC 2006 guidelines for management of patients with ventricular arrhythmias and the prevention of sudden cardiac death: a report of the American College of Cardiology/American Heart Association Task Force and the European Society of Cardiology Committee for Practice Guidelines (Writing Committee to Develop Guidelines for Management of Patients With Ventricular Arrhythmias and the Prevention of Sudden Cardiac Death). J Am Coll Cardiol. 2006:48(5):e247-346.

3. Wellens HJ, Schwartz PJ, Lindemans FW, Buxton AE, Goldberger JJ, Hohnloser SH, Huikuri HV, Kaab S, La Rovere MT, Malik M, Myerburg RJ, Simoons ML, Swedberg K, Tijssen J, Voors AA, Wilde AA. Risk stratification for sudden cardiac death: current status and challenges for the future. Eur Heart J. 2014;35(25):1642-51.

4. Biomarkers Definitions Working G. Biomarkers and surrogate endpoints: preferred definitions and conceptual framework. Clin Pharmacol Ther. 2001; 69(3):89-95.

5. Scott PA, Barry J, Roberts PR, Morgan JM. Brain natriuretic peptide for the prediction of sudden cardiac death and ventricular arrhythmias: a metaanalysis. Eur J Heart Fail. 2009;11(10):958-66

6. Korngold EC, Januzzi JL Jr, Gantzer ML, Moorthy MV, Cook NR, Albert CM. Amino-terminal pro-B-type natriuretic peptide and high-sensitivity Creactive protein as predictors of sudden cardiac death among women. Circulation. 2009:119(22):2868-76.

7. Albert CM, Campos H, Stampfer MJ, Ridker PM, Manson JE, Willett WC, Ma J. Blood levels of long-chain n-3 fatty acids and the risk of sudden death. $\mathrm{N}$ Engl J Med. 2002;346(15):1113-8.

8. Lemaitre RN, King IB, Mozaffarian D, Sotoodehnia N, Rea TD, Kuller LH, Tracy RP, Siscovick DS. Plasma phospholipid trans fatty acids, fatal ischemic heart disease, and sudden cardiac death in older adults: the cardiovascular health study. Circulation. 2006;114(3):209-15.

9. Brouwer IA, Zock PL, Camm AJ, Bocker D, Hauer RN, Wever EF, Dullemeijer C, Ronden JE, Katan MB, Lubinski A, Buschler H, Schouten EG, Group SS. Effect of fish oil on ventricular tachyarrhythmia and death in patients with implantable cardioverter defibrillators: the study on Omega-3 fatty acids and ventricular arrhythmia (SOFA) randomized trial. JAMA. 2006;295(22):2613-9.

10. Kanoupakis EM, Manios EG, Kallergis EM, Mavrakis HE, Goudis CA, Saloustros IG, Milathianaki ME, Chlouverakis GI, Vardas PE. Serum markers of collagen turnover predict future shocks in implantable cardioverter-defibrillator recipients with dilated cardiomyopathy on optimal treatment. J Am Coll Cardiol. 2010;55(24):2753-9.

11. Fu S, Ping P, Zhu Q, Ye P, Luo L. Brain natriuretic peptide and its biochemical, analytical, and clinical issues in heart failure: a narrative review. Front Physiol. 2018;9:692

12. Berger R, Huelsman M, Strecker K, Bojic A, Moser P, Stanek B, Pacher R. Btype natriuretic peptide predicts sudden death in patients with chronic heart failure. Circulation. 2002;105(20):2392-7.

13. Verma A, Kilicaslan F, Martin DO, Minor S, Starling R, Marrouche NF, Almahammed S, Wazni OM, Duggal S, Zuzek R, Yamaji H, Cummings J, Chung MK, Tchou PJ, Natale A. Preimplantation B-type natriuretic peptide concentration is an independent predictor of future appropriate implantable defibrillator therapies. Heart. 2006;92(2):190-5.

14. Simon T, Becker R, Voss F, Bikou O, Hauck M, Licka M, Katus HA, Bauer A Elevated B-type natriuretic peptide levels in patients with nonischemic cardiomyopathy predict occurrence of arrhythmic events. Clin Res Cardiol. 2008;97(5):306-9.

15. Franz MR. Mechano-electrical feedback in ventricular myocardium. Cardiovasc Res. 1996;32(1):15-24.
16. Hansen DE, Craig CS, Hondeghem LM. Stretch-induced arrhythmias in the isolated canine ventricle. Evidence for the importance of mechanoelectrical feedback. Circulation. 1990;81(3):1094-105.

17. Reiter MJ. Effects of mechano-electrical feedback: potential arrhythmogenic influence in patients with congestive heart failure. Cardiovasc Res. 1996; 32(1):44-51.

18. Albert CM, Ma J, Rifai N, Stampfer MJ, Ridker PM. Prospective study of Creactive protein, homocysteine, and plasma lipid levels as predictors of sudden cardiac death. Circulation. 2002;105(22):2595-9.

19. Oliver MF, Opie LH. Effects of glucose and fatty acids on myocardial ischaemia and arrhythmias. Lancet. 1994;343(8890):155-8.

20. Jouven X, Charles MA, Desnos M, Ducimetiere P. Circulating nonesterified fatty acid level as a predictive risk factor for sudden death in the population. Circulation. 2001;104(7):756-61.

21. Kang JX, Leaf A. Prevention of fatal cardiac arrhythmias by polyunsaturated fatty acids. Am J Clin Nutr. 2000;71(1 Suppl):202S-7S.

22. Leaf A, Kang JX, Xiao YF, Billman GE. Clinical prevention of sudden cardiac death by $n-3$ polyunsaturated fatty acids and mechanism of prevention of arrhythmias by $\mathrm{n}-3$ fish oils. Circulation. 2003;107(21):2646-52.

23. Francia P, Uccellini A, Frattari A, Modestino A, Ricotta A, Balla C, Scialla L, Volpe M. Extracellular matrix remodelling in myocardial hypertrophy and failure : focus on osteopontin. High Blood Press Cardiovasc Prev. 2009;16(4): 195-9.

24. Nelson AR, Fingleton B, Rothenberg ML, Matrisian LM. Matrix metalloproteinases: biologic activity and clinical implications. J Clin Oncol. 2000;18(5):1135-49.

25. Klappacher G, Franzen P, Haab D, Mehrabi M, Binder M, Plesch K, Pacher R, Grimm M, Pribill I, Eichler HG, et al. Measuring extracellular matrix turnover in the serum of patients with idiopathic or ischemic dilated cardiomyopathy and impact on diagnosis and prognosis. Am J Cardiol. 1995;75(14):913-8.

26. Francia P, Adduci C, Semprini L, Borro M, Ricotta A, Sensini I, Santini D, Caprinozzi M, Balla C, Simmaco M, Volpe M. Osteopontin and galectin-3 predict the risk of ventricular tachycardia and fibrillation in heart failure patients with implantable defibrillators. J Cardiovasc Electrophysiol. 2014; 25(6):609-16.

27. Rosenberg M, Zugck C, Nelles M, Juenger C, Frank D, Remppis A, Giannitsis E, Katus HA, Frey N. Osteopontin, a new prognostic biomarker in patients with chronic heart failure. Circ Heart Fail. 2008;1 (1):43-9.

28. Priori SG, Schwartz PJ, Napolitano C, Bloise R, Ronchetti E, Grillo M, Vicentini A, Spazzolini C, Nastoli J, Bottelli G, Folli R, Cappelletti D. Risk stratification in the long-QT syndrome. N Engl J Med. 2003;348(19):1866-74.

29. Benito B, Sarkozy A, Mont L, Henkens S, Berruezo A, Tamborero D, Arzamendi D, Berne P, Brugada R, Brugada P, Brugada J. Gender differences in clinical manifestations of Brugada syndrome. J Am Coll Cardiol. 2008; 52(19):1567-73.

30. Sieira J, Conte G, Ciconte G, de Asmundis C, Chierchia GB, Baltogiannis G, Di Giovanni G, Saitoh Y, Irfan G, Casado-Arroyo R, Julia J, La Meir M, Wellens F, Wauters K, Pappaert G, Brugada P. Clinical characterisation and long-term prognosis of women with Brugada syndrome. Heart. 2016;102(6):452-8.

31. Lin CY, Chung FP, Lin YJ, Chang SL, Lo LW, Hu YF, Tuan TC, Chao TF, Liao JN, Chang YT, Chen YY, Walia R, Te ALD, Yamada S, Chen SA. Gender differences in patients with arrhythmogenic right ventricular dysplasia/ cardiomyopathy: clinical manifestations, electrophysiological properties, substrate characteristics, and prognosis of radiofrequency catheter ablation. Int J Cardiol. 2017;227:930-7.

32. Akdis D, Saguner AM, Shah K, Wei C, Medeiros-Domingo A, von Eckardstein A, Luscher TF, Brunckhorst C, Chen HSV, Duru F. Sex hormones affect outcome in arrhythmogenic right ventricular cardiomyopathy/dysplasia: from a stem cell derived cardiomyocyte-based model to clinical biomarkers of disease outcome. Eur Heart J. 2017;38(19):1498-508.

33. Gao G, Xie A, Zhang J, Herman AM, Jeong EM, Gu L, Liu M, Yang KC, Kamp TJ, Dudley SC. Unfolded protein response regulates cardiac sodium current in systolic human heart failure. Circ Arrhythm Electrophysiol. 2013;6(5):1018-24.

34. Shang LL, Pfahnl AE, Sanyal S, Jiao Z, Allen J, Banach K, Fahrenbach J, Weiss D, Taylor WR, Zafari AM, Dudley SC Jr. Human heart failure is associated with abnormal C-terminal splicing variants in the cardiac sodium channel. Circ Res. 2007;101(11):1146-54.

35. Gao G, Brahmanandam V, Raicu M, Gu L, Zhou L, Kasturirangan S, Shah A, Negi SI, Wood MR, Desai AA, Tatooles A, Schwartz A, Dudley SC Jr. Enhanced risk profiling of implanted defibrillator shocks with circulating 
SCN5A mRNA splicing variants: a pilot trial. J Am Coll Cardiol. 2014;63(21): 2261-9.

36. Dekker LR, Bezzina CR, Henriques JP, Tanck MW, Koch KT, Alings MW, Arnold AE, de Boer MJ, Gorgels AP, Michels HR, Verkerk A, Verheugt FW, Zijlstra F, Wilde AA. Familial sudden death is an important risk factor for primary ventricular fibrillation: a case-control study in acute myocardial infarction patients. Circulation. 2006;114(11):1140-5.

37. Jouven $X$, Desnos M, Guerot C, Ducimetiere P. Predicting sudden death in the population: the Paris prospective study I. Circulation. 1999;99(15): 1978-83.

38. Kaikkonen KS, Kortelainen ML, Linna E, Huikuri HV. Family history and the risk of sudden cardiac death as a manifestation of an acute coronary event. Circulation. 2006;114(14):1462-7.

39. Albert CM, MacRae CA, Chasman DI, VanDenburgh M, Buring JE, Manson JE, Cook NR, Newton-Cheh C. Common variants in cardiac ion channel genes are associated with sudden cardiac death. Circ Arrhythm Electrophysiol. 2010;3(3):222-9.

40. Francia P, Adduci C, Ricotta A, Stanzione R, Sensini I, Uccellini A, Frattari A, Balla C, Cotugno M, Cappato R, Rubattu S, Volpe M. Common genetic variants in selected $\mathrm{Ca}(2)(+)$ signaling genes and the risk of appropriate ICD interventions in patients with heart failure. J Interv Card Electrophysiol. 2013:38(3):169-77.

41. Sesti F, Abbott GW, Wei J, Murray KT, Saksena S, Schwartz PJ, Priori SG, Roden DM, George AL Jr, Goldstein SA. A common polymorphism associated with antibiotic-induced cardiac arrhythmia. Proc Natl Acad Sci U S A. 2000;97(19):10613-8.

42. Arking DE, Junttila MJ, Goyette P, Huertas-Vazquez A, Eijgelsheim M, Blom MT, Newton-Cheh C, Reinier K, Teodorescu C, Uy-Evanado A, Carter-Monroe N, Kaikkonen KS, Kortelainen ML, Boucher G, Lagace C, Moes A, Zhao X, Kolodgie F, Rivadeneira F, Hofman A, Witteman JC, Uitterlinden AG, Marsman RF, Pazoki R, Bardai A, Koster RW, Dehghan A, Hwang SJ, Bhatnagar P, Post W, Hilton G, Prineas RJ, Li M, Kottgen A, Ehret G, Boerwinkle E, Coresh J, Kao WH, Psaty BM, Tomaselli GF, Sotoodehnia N, Siscovick DS, Burke GL, Marban E, Spooner PM, Cupples LA, Jui J, Gunson K, Kesaniemi YA, Wilde AA, Tardif JC, O'Donnell CJ, Bezzina CR, Virmani R, Stricker BH, Tan HL, Albert CM, Chakravarti A, Rioux JD, Huikuri HV, Chugh SS. Identification of a sudden cardiac death susceptibility locus at 2q24.2 through genome-wide association in European ancestry individuals. PLoS Genet. 2011;7(6):e1002158.

43. Bezzina CR, Pazoki R, Bardai A, Marsman RF, de Jong J, Blom MT, Scicluna BP, Jukema JW, Bindraban NR, Lichtner P, Pfeufer A, Bishopric NH, Roden DM, Meitinger T, Chugh SS, Myerburg RJ, Jouven X, Kaab S, Dekker LRC, Tan HL, Tanck MWT, Wilde AAM. Genome-wide association study identifies a susceptibility locus at 21 q21 for ventricular fibrillation in acute myocardial infarction. Nat Genet. 2010;42(8):688-91.

44. Ripatti S, Tikkanen E, Orho-Melander M, Havulinna AS, Silander K, Sharma A, Guiducci C, Perola M, Jula A, Sinisalo J, Lokki ML, Nieminen MS, Melander O, Salomaa V, Peltonen L, Kathiresan S. A multilocus genetic risk score for coronary heart disease: case-control and prospective cohort analyses. Lancet. 2010:376(9750):1393-400.

45. Abriel H, Zaklyazminskaya EV. Cardiac channelopathies: genetic and molecular mechanisms. Gene. 2013;517(1):1-11.

46. Zareba W, Moss AJ, Schwartz PJ, Vincent GM, Robinson JL, Priori SG, Benhorin J, Locati EH, Towbin JA, Keating MT, Lehmann MH, Hall WJ. Influence of the genotype on the clinical course of the long-QT syndrome. International long-QT syndrome registry research group. N Engl J Med. 1998;339(14):960-5.

47. Brink PA, Crotti L, Corfield V, Goosen A, Durrheim G, Hedley P, Heradien M, Geldenhuys G, Vanoli E, Bacchini S, Spazzolini C, Lundquist AL, Roden DM, George AL Jr, Schwartz PJ. Phenotypic variability and unusual clinical severity of congenital long-QT syndrome in a founder population. Circulation. 2005;112(17):2602-10.

Ready to submit your research? Choose BMC and benefit from:

- fast, convenient online submission

- thorough peer review by experienced researchers in your field

- rapid publication on acceptance

- support for research data, including large and complex data types

- gold Open Access which fosters wider collaboration and increased citations

- maximum visibility for your research: over $100 \mathrm{M}$ website views per year

At BMC, research is always in progress.

Learn more biomedcentral.com/submissions 